\title{
Law Enforcement Model in Community Based Waste Monitoring and Management as a Realization of Good Environmental Governance Principles in West Sumatera, Indonesia
}

\author{
Lona Puspita, Meita Lefi Kurnia and Yevendri \\ Faculty of Law, Universitas Tamansiswa, Padang, Indonesia \\ E-mail : lonapuspita@unitas_pdg.ac.id
}

How to cite : Lona Puspita; Meita Lefi Kurnia and Yevendri. (2019). Law Enforcement Model in Community Based Waste Monitoring and Management as a Realization of Good Environmental Governance Principle in Wast Sumatra, Indonesia . UNIFIKASI : Jurnal IImu Hukum, 6(1), 1-6. DOI : 10.25134/unifikasi.v6i1.1629 Submitted : 17-01-2019 Revised : 01-06-2019 Accepted : 20-08-2019

\begin{abstract}
The increasing number of population and industry will have an impact on the number of waste produced, such as plastic waste, paper waste, and packaging products containing toxic materials. This research aims to create a law enforcement model in community-based waste monitoring and management as a realization of the principles of Good Environmental Governance. The research method used was empirical juridical. The results showed that the law enforcement model adapted in community-based waste monitoring and management to realize good environmental governance in West Sumatra Province is started from the monitoring carried out by the community towards the community members littering or do not do waste sorting in which its results will be reported to the Department of Environment. In addition to being based on regional regulations, the law enforcement model is also carried out in the form of social sanctions in which the persons will be being announced on social media for 30 days or participating in various programs conducted by the Department of Environment for 30 days. Hence, community involvement must start from the management, processing, monitoring, and law enforcement.
\end{abstract}

Keywords: Law enforcement; Waste Monitoring and Management; Community-Based; Principles of Good Environmental Governance.

\section{Model Penegakan Hukum dalam Pengawasan dan Pengelolaan Sampah Berbasis Masyarakat sebagai Perwujudan Prinsip Good Environmental Governance di Sumatera Barat, Indonesia}

\begin{abstract}
Abstrak : Peningkatan jumlah penduduk dan usaha industri akan memberikan pengaruh terhadap sampah yang akan dihasilkan seperti sampah plastik, kertas, produk kemasan yang mengandung Bahan Beracun Berbahaya. Tujuan penelitian ini adalah bagimana membuat model penegakan hukum dalam pengawasan dan berbasis masyarakat sebagai perwujudan prinsip Good Environmental Governance. Metode penelitian ini bersifat yuridis empiris. Hasil penelitian ini model penegakan hukum dalam pengawasan dan pengelolaan sampah berbasis masyarakat demi terwujudnya Good Environmental Governance di Provinsi Sumatera Barat dimulai dari pengawasan yang dilakukan oleh masyarakat terhadap warga yang membuang sampah sembarangan atau yang tidak melakukan pilah sampah, yang hasilnya nanti dilaporkan ke Dinas Lingkungan Hidup kota setempat. Model penegakan hukum yang dilakukan selain berdasarkan Peraturan Daerah setempat juga penegakan hukum dalam bentuk sanksi sosial berupa di umumkan dalam media sosial selama 30 hari atau ikut serta dalam program Dinas Lingkungan Hidup setempat selama 30 hari. Keterlibatan masyarakat harus dimulai dari pengelolaan, pengolahan, pengawasan dan penegakan hukumnya

Kata Kunci: Penegakan Hukum; Pengawasan dan Pengelolaan Sampah; Berbasis Masyarakat; Prinsip Good Environmental Governance.
\end{abstract}

\section{INTRODUCTION}

Law enforcement is an interesting issue to study since it is related to the implementation of the applicable legislations. The enforcement of environmental law is closely related to all aspects of human 
life since environment is a buffer for human life on earth. ${ }^{1}$ The waste phenomenon in Indonesia is hardly to eliminate. Yet, this problem will not be long if everyone is aware and understands the impact of waste. In Indonesia, $60-70 \%$ of the total waste produced is organic waste originating from traditional markets and settlements. ${ }^{2}$ In addition to clothing, food and settlements, it is indisputable that a good and healthy environment is a basic human need. In developed countries like China, polluted air has become a "killer" of 4.000 people every day or around 1.6 million people each year due to heart disease, lung disease and stroke. ${ }^{3}$ In addition to air, another basic human need is clean water. Water is the heart of life. All human activities need water. The amount of clean water is unlimited. Yet, the increasing number of population and the decrease level of public awareness towards the environment have caused a decrease in the quality and quantity of clean water. Beside air and water pollution, waste is also an environmental problem especially in developing countries, like Indonesia. The increase level of economic growth in Indonesia from year to year is always followed by population growth. As a result of population growth, humans tend to damage the environment in order to maintain their lives. The quality of the environment is continuously decreasing, resulting in environmental degradation in human life. One of the environmental problems faced in urban areas is waste management.

Household waste management that is commonly done by local governments is waste management based on landfills in which its core management is the collection, transportation and disposal of waste. ${ }^{4}$ Waste monitoring and management currently becomes a major concern in Indonesia, including in West Sumatra Province. Some regencies and cities in West Sumatra already have Regional Regulations (Perda) concerning waste management. Yet, until now, its implementation has not run optimally. Considering that the environment has a vital role in human life, the environment must be well managed so that it is not damaged and polluted. Thus, the principles of good environmental governance must be adopted in environmental management in order to achieve the expected environmental management. Based on the description, this research intends to create a law enforcement model in community-based waste monitoring and management as a realization of the principles of Good Environmental Governance.

\section{RESEARCH METHODS}

The method used in this research was empirical juridical research method. Here, the data were collected through observation, interviews and questionnaires. This research was carried out in 2 (two) cities in West Sumatra Province, namely Padang City and Payakumbuh City. The sites were chosen because they are big cities in West Sumatra Province which have large landfill sites.

\section{RESULTS AND DISCUSSION}

\section{Law Enforcement in Waste Monitoring and Management in Padang City and Payakumbuh City, West Sumatra.}

First is Institutional Aspect. Waste management in Padang City is carried out by the Department of Environment, Padang City. The expected involvement of the private sectors in waste operational activities includes the stage of transportation, management and final disposal. Yet, until now, no one

\footnotetext{
${ }^{1}$ Suwari Akhmaddhian ,Penegakan Hukum Lingkungan dan Pengaruhnya Terhadap Pertumbuhan Ekonomi di Indonesia, Jurnal Unifikasi Vol. 03 Nomor 01 Januari 2016, hal 2

${ }^{2}$ Agus ramon, afriyanto, , Karakteristik Penanganan Sampah Rumah Tangga di Kota Bengkulu, Jurnal Kesehatan Masyarakat Andalas, Fakultas Kesehatan Masyarakat Universitas Andalas 2015

3 www.washingtonpost.com, Air Pollution in China is Killing 1.6 million People a Year,Researchers say, 14 August 2015

${ }^{4}$ Beta Dwi Utami, Nastiti Siswi Insrasti dan Arya hadi Dharmawan, Sociality : Jurnal Transdisiplin Sosiologi, Komunikasi dan Ekologi Manusia, Vil.2 No 01, April 2008, Hal 49
} 
has participated. ${ }^{5}$ Second is Legal and Regulatory Aspects. Basically, there have been regional regulations regulating waste management, such as Padang Regional Regulation No. 21 of 2012 and Payakumbuh Regional Regulation No. 4 of 2014 concerning waste management. However, up to now, there has not been strict legal sanction imposed on the community violating this regulation. Third is Community Participation Aspect. This aspect is very important in carrying out the applicable waste management. Yet, in fact, people are accustomed to throwing waste in the yard of the house or in the river so that this behavior can be said to be bad. Although changing people's behavior is considered difficult, but it does not mean impossible. Continuous coaching will be optimal in changing people's behavior.

Padang City is the largest city on the west coast of the island of Sumatra as well as the capital of West Sumatra Province. Padang city has a coastline of $\pm 68.13 \mathrm{KM}$ with a population of \pm 930.901 . Its administrative area has a total area of $694.96 \mathrm{KM}^{2}$ which is divided into 11 Districts and 104 Subdistricts. ${ }^{6}$ The population which is almost 1 million people as well as its geographical location located on the coast cause waste issue to become a serious problem in Padang City. With such a large population, of course, household waste will also be huge so that the Department of Environment will not be able to handle all wastes. The household waste produced achieves \pm 500 tons/day and the amount that can be transported only \pm 400 tons $/ \mathrm{day}^{7}$. It means that there is still \pm 100 tons/day of waste that is still not well managed. These wastes are then processed by the community through the $3 \mathrm{R}$ program.

Table 1.

Model of Household Waste Management through the 3R Program

\begin{tabular}{|l|l|}
\hline Reuse & $\begin{array}{l}\text { A. Reuse the reusable containers/packaging } \\
\text { B. Sell or give sorted waste to parties that need it }\end{array}$ \\
\hline Reduce & $\begin{array}{l}\text { A. Choose products with reusable packaging } \\
\text { B. Use refilled products } \\
\text { C. Reduce the use of disposable materials }\end{array}$ \\
\hline Recycle & $\begin{array}{l}\text { A. Do organic waste processing into compost } \\
\text { B. Do non-organic waste processing into useful goods }\end{array}$ \\
\hline
\end{tabular}

Further, concrete step that has been taken by the government of Padang City in reducing waste piles is by issuing circular letter concerning "Saturday without Plastic Bags". Yet, this step has not yet run optimally due to the lack of socialization carried out by the government so that many people do not know about this circular letter. Besides, various efforts to improve facilities and infrastructure have also been carried out by the Department of Environment, such as the K3 patrols at District or Sub-districts level, the 114 units of Waste Management Institution (LPS), 500 cleanliness volunteers and 1000 cadres of waste management/year. ${ }^{8}$ These efforts are considered successful in reducing waste piles in Padang City. Besides, the procedure of transporting waste from the Temporary Waste Disposal Site (TPSS) to Final Disposal Site (TPA) has also been well managed.

\footnotetext{
${ }^{5}$ Interview with Mr. Tri, Secretary of the Padang City Environment Agency

${ }^{6}$ www.bps.go.id

${ }^{7}$ Interview with Mr. Ir.Tri Hadiyanto, Secretary of the Padang City Environment Agency

${ }^{8}$ Ibid
} 


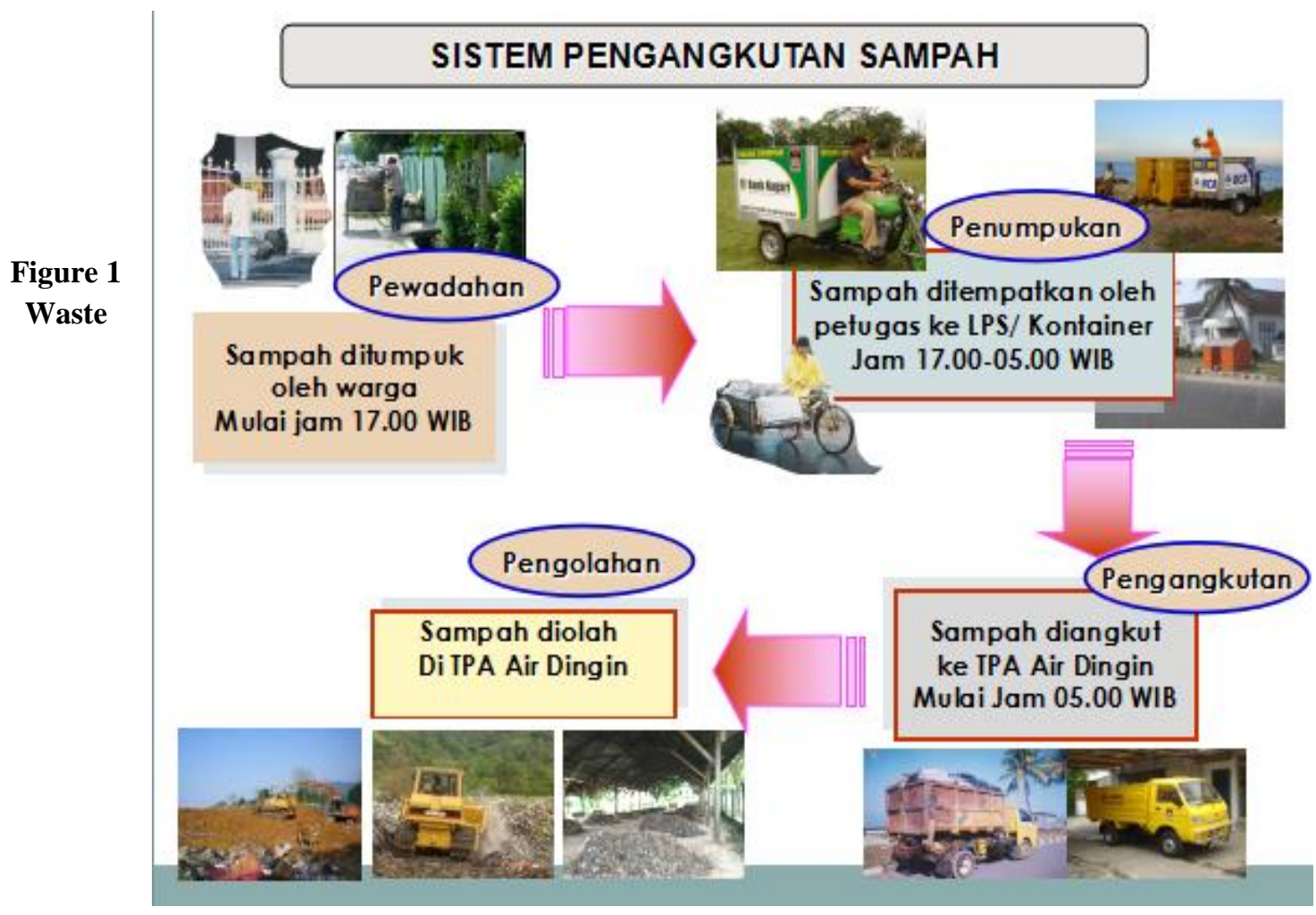

Transportation System

Efforts taken by the Department of Environment in reducing waste piles have been optimal, but it is not accompanied by community awareness in reducing and sorting waste as well as many people littering, especially people who live on river banks. Sanction towards the violation of Padang Regional Regulation No. 21 of 2012 concerning Waste Management has been carried out in the form of a trial, but this action is not carried out on an ongoing basis.

Payakumbuh city is located in the highlands which are part of the Bukit Barisan. Payakumbuh is about $30 \mathrm{~km}$ from Bukittinggi City or $120 \mathrm{~km}$ from Padang City. The administrative area of the city is surrounded by Lima Puluh Kota Regency with an area of $80.34 \mathrm{~km}^{2}$.

Waste management in Payakumbuh City has not been carried out based on Regional Regulation No. 4 of 2014 concerning Waste Management since it is still in the process of socializing to the community. The landfill of Payakumbuh City is a regional landfill in which its monitoring is directly under the Department of Environment, West Sumatra Province. The waste disposed of this landfill comes from Payakumbuh City, Bukititnggi City, Lima Puluh Kota Regency, and Agam Regency ${ }^{9}$ with amount of \pm 650 tons/day. From this amount, there are only \pm 400 tons/day of waste that can be transported. The remaining \pm 150 tons/day are processed by the community in the form of a waste bank and an integrated waste management at sub-districts level, such as the integrated waste management in Ibuh Market. In Ibuh Market, waste management originating from activities in Ibuh Market is carried out every day starting at 10:00 am. ${ }^{10}$ From January to March 2018, the amount of waste processed at Ibuh Market is $35.003 \mathrm{~kg}$ which then became $13.600 \mathrm{~kg}$ of compost. ${ }^{11}$ In addition to the socialization of Regional Regulation, the government of Payakumbuh City has also issued a circular letter of

\footnotetext{
${ }^{9}$ Interview with Mr. Novi as Officer / operator in the Payakumbuh Regional Landfill

${ }^{10}$ Interview with Mr. Riki as a waste manager in Ibuh Market

${ }^{11}$ Interview with Mr. Riko As Waste Manager in Ibuh Market
} 
Payakumbuh City No. 660.931/WK-PYK/2018 concerning the Enforcement of Regional Regulation No. 4 of 2014. This Circular Letter is also in the socialization stage.

\section{Law Enforcement Model in Community-Based Waste Monitoring and Management to Realize Good Environmental Governance in West Sumatra Province}

The active participation of the community in managing household waste will determine the success of its implementation. The community needs to be empowered with all non-instructive efforts to increase their knowledge and ability to be able to identify problems as well as plan and solve problems by utilizing the potential of local communities. ${ }^{12}$

From the investigation done in Padang City and Payakumbuh City, we have developed a model of law enforcement in community-based waste monitoring and management to realize good environmental governance in West Sumatra Province as follows:

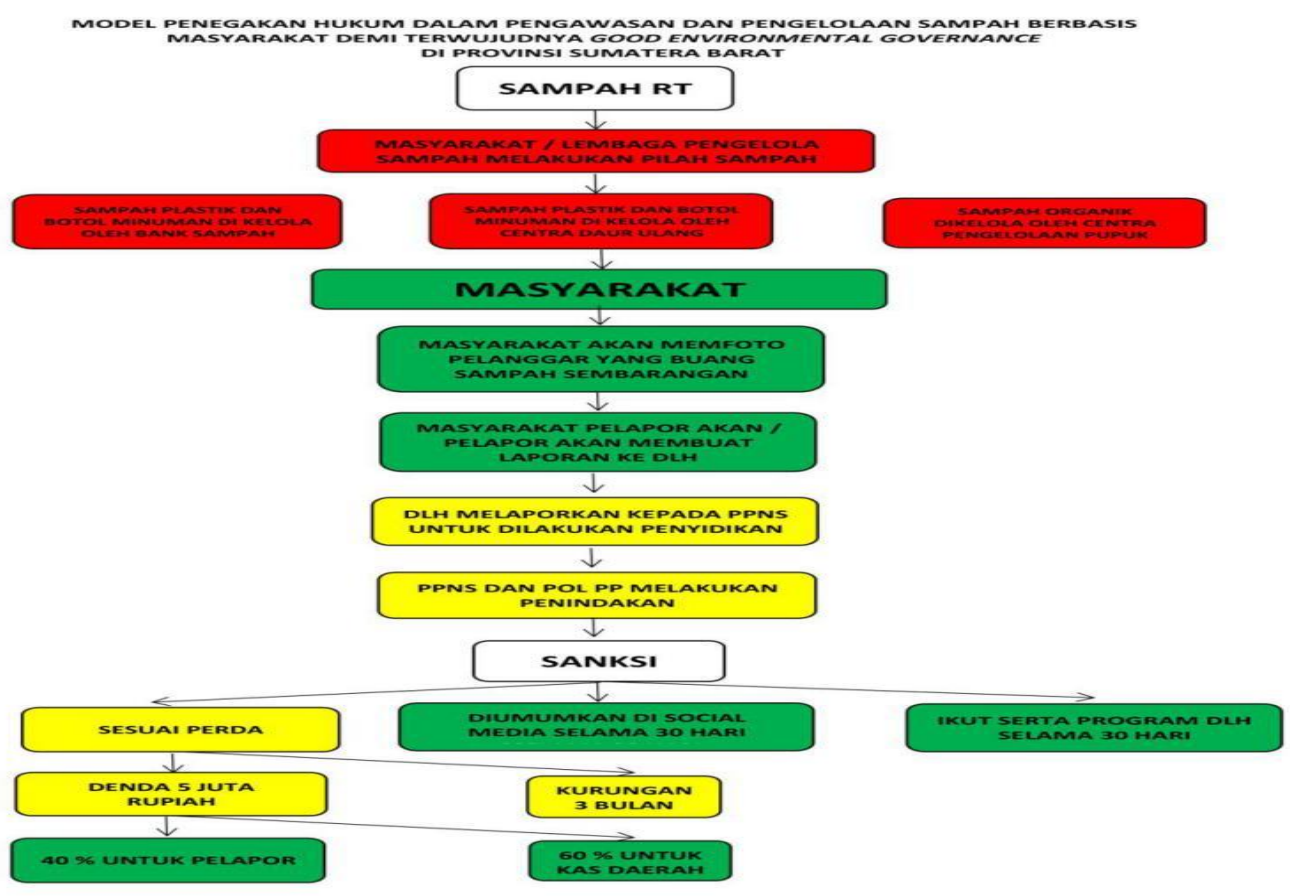

Notes :

\begin{tabular}{|l|l|}
\hline Red & $\begin{array}{l}\text { The model of household waste management that must be carried out by the community is in } \\
\text { the form of waste sorting in which its results can be collected to the existing waste bank at sub- } \\
\text { district level. Besides, the waste management done by the community can also be in the form } \\
\text { of recycling or processing waste into compost. }\end{array}$ \\
\hline Green & $\begin{array}{l}\text { The law enforcement model in household waste monitoring and management carried out by the } \\
\text { community. For those who find community members littering or do not do waste sorting, they } \\
\text { should report it to the Department of Environment. There are two community-based sanctions, } \\
\text { namely the persons littering will be being announced on social media for 30 days or taking an } \\
\text { active participation in a program conducted by the Department of Environment to clean the } \\
\text { environment for 30 days. }\end{array}$ \\
\hline Yellow & $\begin{array}{l}\text { The process of law enforcement in waste monitoring and management is in accordance with } \\
\text { the regional regulations. }\end{array}$ \\
\hline
\end{tabular}

${ }^{12}$ Riswan, Henna Rya Sunako,Agus Hadiyanto, Jurnal Ilmu Lingkungan, Vol 9 No 1,Pengelolaan sampah rumah tangga di kecmatan Doha Selatan,2011 


\section{CONCLUSION}

The law enforcement model in community-based waste monitoring and management to realize good environmental governance in West Sumatra Province is started from the monitoring carried out by the community towards the community members littering or do not do waste sorting in which its results will be reported to the Department of Environment. In addition to being based on regional regulations, the law enforcement is also carried out in the form of social sanctions in which the persons littering will be being announced on social media for 30 days or participating in various programs conducted by the Department of Environment for 30 days. Finally, it is expected that this model can be applied so that the waste monitoring and management is not only carried out by the Department of Environment, but it also involves the active role of the community in maintaining environmental cleanliness.

\section{SUGGESTION}

By paying attention to the weaknesses in the formulation/legislation policy relating to the corporate criminal liability system in 124 (one hundred twenty four) special criminal legislations spread outside the Criminal Code (KUHP), in order to overcome corporate criminal acts and national criminal law reform (penal reform), it is necessary to reorient and reformulate concerning the definition of corporation, the party that should bear criminal liability, classification/categorization of actions as corporate criminal acts, and the type of criminal sanctions against a corporation committing a criminal act.

\section{REFERENCES}

Agus Ramon dan Afriyanto. (2015). “ Karakterikstik Penanganan Sampah Rumah Tangga di Kota Bengkulu” Jurnal Kesehatan Masyarakat Andalas, Vol.10 No 01. 2015.

Aisyah, (2013),"Pengelolaan Sampah Rumah Tangga Berbasis Masyarakat di Rumah Tangga kelurahan Sungai Pinang Kecamatan Samarinda Utara, Jurnal Beraja Niti, Vol. 2 No. 12. 2013.

Beta Dwi Utami, Nastiti Siswi Indrasti, Arya hadi Dharmawan, (2010)"Pengelolaan Sampah Rumah

Tangga Berbasis Komunitas" Sodality : Jurnal Transdisipil Sosiologi, Komunikasi dan Edukasi Manusia, Vol 02 No 10. 2010.

Esmi Warasih. (2005). Pranata Hukum, Sebuah Telaah Sosiologis. Semarang : PT $\quad$ Suryandaru

Utama.

Mulyanto. (2013). "Sistem Pengelolaan Sampah Terpadu (Sipengestu) Kelurahan Serengan dalam

Kajian Sosiologi Hukum”. Jurnal Parental. Volume I Nomor 2 Tahun 2013.

Nopyandri. (2011). "Penerapan Prinsip Good Environmental Governance dalam Perda Kabupaten

Sleman Provinsi Daerah Istimewa Yogyakarta. Jurnal Ilmu Hukum, Volume 2 No.1. 2011.

Peter Mahmud Marzuki. (2010). Penelitian Hukum Normatif. Jakarta : Kencana Prenada Media Group.

Ridwan HR. (2011). Hukum Administrasi Negara Edisi Revisi.

Risman, Henna Rya Sunoko dan Agus Hadiyato. (2011),"Pengelolaan Sampah Rumah Tangga di Kecamatan Daha Selatan", Jurnal Ilmu Lingkungan Vol.9, No. 1, April 2011.

Suwari Akhmaddhian ,(2016), Penegakan Hukum Lingkungan dan Pengaruhnya Terhadap Pertumbuhan Ekonomi di Indonesia, Unifikasi : Jurnal Ilmu Hukum. Vol. 03 No 01. 2016.

Waluyo, Ayub Torry Satriyo Kusumo dan Rosita Candrakirana. (2012). Laporan Penelitian Hibah Bersaing dengan judul Model Pengelolaan Sampah Kota Berbasis Gender Sebagai Upaya Pengentasan Kemiskinan. Surakarta. Fakultas Hukum Universitas Sebelas Maret. 